\title{
Morfología macroscópica de alteración de la piedra de la Catedral de Baeza, Jaén (España)
}

\section{Macroscopical morphology of deterioration of the stone in the Cathedral of Baeza, Jaen (Spain)}

\author{
M. ALCALDE ${ }^{\star}$, G. G. TERREROS ${ }^{\star \star}$ R. VILLEGAS ${ }^{\star}$ \\ * Dpto. de Ingeniería Química y Ambiental. **Dpto. de Construcciones Arquitectónicas II \\ Universidad de Sevilla
}

Fecha de recepción: 11-XII-97

ESPAÑA

Fecha de aceptación: 4-III-98

\section{RESUMEN}

Los principales factores de alteración que afectan a la Catedral de Baeza son de origen natural, fundamentalmente de tipo térmico e hidráulico. Para la construcción se han empleado en su mayor parte dos tipos de calcarenita, una franca de porosidad media y otra más dura y compacta procedentes de canteras de la zona. Los mecanismos de alteración más frecuentes son los ligados a la cristalizacióndisolución e hidratación-deshidratación de sales, así como a los de heladicidad en interior de los poros. Se hace una descripción por fachadas de los indicadores de alteración, siendo los más frecuentes las fisuras, arenizaciones $y$ disyunciones.

\section{SUMMARY}

The main factors of deterioration that affect the Cathedral of Baeza are of a natural origin, basically thermic and hydraulic. Two types of calcarenite were employed in the construction of the major part of this building: one "franca" of medium porosity and another "viva" harder and more compact, both extracted from the quarries in the area. The most frequent mechanisms of deterioration are those bound to crystallization-dissolution and hydration-dehydration of salts, as well as freezing inside the pores. Façade-by-façade description of the deterioration indicators is provided; the most common ones tend to be fissures, grain disgregations and disjunctions.

\section{INTRODUCCIÓN}

La Catedral de Baeza, Jaén (España) fue construida en su mayor parte en el siglo XVI, sobre una antigua mezquita que, a su vez, sustituía a un antiguo templo romano dedicado a Marte. Los elementos más antiguos se encuentran en la fachada occidental, como la mudéjar Puerta de la Luna, del siglo XIII, y el rosetón gótico, del XIV. La Puerta del Perdón de la fachada meridional es del XV. La base de la torre, antiguo

\section{INTRODUCTION}

The Cathedral of Baeza (Jaén, Spain) was built mainly in the XVI century, over an old mosque which, in its turn, was in the place of an old roman temple consecrated to Mars. The oldest elements can be found in the western façade, such as the mudejar Moon Door, of the XIII century, and the gothic rose window, of the $X I V$ century. Forgiveness Door in the southern façade is of the $X V$ century. The tower base, an old minaret of 
alminar de la mezquita, data de 1395 , pero el segundo cuerpo se desplomó en 1862 y se inició una reconstrucción que terminó en 1960 (Ayala, 1982; Mejías, 1989).

Las construcciones que constituyen la catedral se adosan o superponen, unas sobre otras, y ésta aparece como un conglomerado de fábricas y una superposición de estilos arquitectónicos. Las extensiones de las distintas actuaciones resultan a veces difíciles de determinar. En lo concerniente a los muros, a veces presentan mamposterías claramente distinguibles, mientras en otras ocasiones varias fases constructivas están mezcladas.

\section{ENTORNO AMBIENTAL}

La Catedral de Baeza está ubicada en el casco urbano, en un lugar alto, bien barrido por los vientos. La fachada principal, orientada al N-NO, está precedida por una gran plaza desde la que se accede a través de una amplia escalinata. En el resto de su perímetro está rodeada de calles estrechas, con escaso o nulo tráfico rodado, $\mathrm{y}$, hasta hace poco, de algunos volúmenes adosados que están siendo eliminados.

\subsection{Clima}

Baeza pertenece a la región climática continental extremada meseta sur. Las temperaturas son extremas a lo largo del año, con inviernos rigurosos y veranos calurosos. El número medio de días de helada $\left(\mathrm{T}<0^{\circ} \mathrm{C}\right)$ al año es de 20 y la media de las temperaturas mínimas en el mes más frío, enero, es de $3^{\circ} \mathrm{C}$. No se dispone de datos acerca de la frecuencia con que se alcanzan temperaturas inferiores a $-4{ }^{\circ} \mathrm{C}$ en que se generan los mecanismos de gelivación, pero es evidente que éstos han de ser importantes en la alteración de la piedra en el edifíco. Julio es el mes más cálido, con una media en sus temperaturas máximas diarias de $34^{\circ} \mathrm{C}$, y a lo largo del año de 120 a 150 días la temperatura máxima supera los $25^{\circ} \mathrm{C}$. Las oscilaciones diarias de temperatura (máxima-mínima) son máximas en julio y agosto, con $13{ }^{\circ} \mathrm{C}$ de oscilación, y mínimas en diciembre, $\operatorname{con} 6^{\circ} \mathrm{C}$.

La humedad relativa alcanza sus valores máximos en enero, con una media, en sus valores punta (a las $7 \mathrm{~h}$ ), del $85-90 \%$, siendo julio el mes más seco, con una media de sus valores mínimos (a las $13 \mathrm{~h}$ ) del $30-35 \%$. Las máximas oscilaciones durante el día en la humedad relativa, comparando los valores medios a las 7 y a las 13 horas, se observan en el mes de julio $60-65$ y $30-35 \%$ respectivamente) y las mínimas en enero (85-90 y $70 \%$ respectivamente). the mosque, is dated in 1395, but the second body collapsed in 1862 and a reconstruction work was started, wich ended in 1960 (Ayala, 1982; Mejias, 1989).

The cathedral appears as a masonry conglomeration and as a superposition of architectural styles, its buildings being one lapped over or leaned against another. Sometimes the extent of the different actuations result difficult to determine. With respect to the walls, their rubblework is sometimes neatly distinguishable, while in other cases, different phases of the construction appear to be mixed up.

\section{ENVIRONMENTAL SURROUNDINGS}

The Cathedral of Baeza is located within the city, on high ground, well swept by the winds. The main façade, $\mathrm{N}-\mathrm{NW}$ oriented, is preceded by a great square and wide front steps, which provides the access. The rest of the building perimeter is surrounded by narrow streets, with little or no traffic, and, since not long, by some attached volumes which are being eliminated.

\subsection{Climate}

Baeza belongs to the extreme continental climatical region, southern plateau. Temperatures are extreme along the year, with severe cold winters and hot summers. The average number of frosts $\left(T<0^{\circ} \mathrm{C}\right)$ is of 20 days a year, and the average minimum temperature in the coldest month, january, is $3{ }^{\circ} \mathrm{C}$. Data about the frequency of temperatures generating frosts mechanisms $\left(T<-4^{\circ} \mathrm{C}\right)$ are not available, but the importance of such temperatures in the stone deterioration is evident. July is the hottest month, with a daily maximum temperature of $34^{\circ} \mathrm{C}$, and along the year, the maximum temperature is over $25^{\circ} \mathrm{C}$ from 120 to 150 days. Temperature daily oscillations (maximumminimum) are maximum in july and august, with oscillations of $13{ }^{\circ} \mathrm{C}$, and minimum in december, with $6{ }^{\circ} \mathrm{C}$.

The relative humidity gives its maximum in January with average highest values of $85-90 \%$ at $7 \mathrm{~h}$., and the driest month is july, with average minimum values of $30-35 \%$ at $13 \mathrm{~h}$. Comparing the average values at 7 and $13 \mathrm{~h}$., the maximum oscillations in relative humidity during the day occur in july (60-65 and $30-35 \%$ respectively) and the minimum oscillations in january (85-90 and $70 \%$ respectively). 
La precipitación media anual es de $500 \mathrm{l} / \mathrm{m}^{2}$. Marzo es el mes de mayor media pluviométrica, con $801 / \mathrm{m}^{2}$ y julio el de menor, con $51 / \mathrm{m}^{2}$. La precipitación máxima en 24 horas es de $100 \mathrm{1} / \mathrm{m}^{2}$. Se registran de 1 a 5 días de nevada al año.

Los vientos dominantes a lo largo del año son del sudoeste $(\mathrm{SO})$, de carácter fiojo. La velocidad media anual es de $10 \mathrm{~km} / \mathrm{h}$, siempre inferiores a $50 \mathrm{~km} / \mathrm{h}$ y el $75 \%$ de las veces inferiores a $20 \mathrm{~km} / \mathrm{h}$. La radiación solar es de 4,75-5 kwh/m² día. Se registran $2.900 \mathrm{~h}$ de insolación anuales, siendo ésta máxima en el mes de juilio (390 h.) y mínima en enero (160 h.). La evapotranspiración potencial media anual (fórmula de Thornthwaite) es de $9501 / \mathrm{m}^{2}$

\subsection{Contaminación}

No se dispone de datos numéricos de contaminación atmosférica, pero dadas las características urbanísticas de la zona, la topografía del terreno (monumento en zona alta bien venteada) y la escasez de tráfico rodado, es factible suponer que la contaminación de tipo ácido, a la que es más sensible este tipo de piedra, es poco significativa.

\subsection{Subsuelo}

Cabía esperar que, por la mencionada situación topográfica, la capa freática no fuese una fuente de aporte hídrico, sin embargo, se observan diversos lugares en el edificio donde es importante la humedad ascendente.

\section{MATERIALES PÉTREOS}

En la construcción del edificio se han empleado, principalmente, dos tipos de piedra, una "franca", de fácil laboreo y porosidad media, y otra "viva", dura, más compacta y densa. Ambas de color amarillo ocre, en la meteorización tienden a colores más oscuros, pero en general la franca suele quedar en color marrón y la viva llega a alcanzar una tonalidad gris. También se encuentra un tipo con estratos de diferentes colores, unos azules de aspecto pizarroso y otros amarillos, y que en la zona recibe el nombre de "jabaluna". En el presente trabajo se estudian muestras de los diversos tipos mencionados, obtenidas en el monumento (Tabla I). E. Sebastián (1995) ha caracterizado muestras de las canteras Atalayon, al sur de la ciudad, y R. Villegas (1990) otras obtenidas en derribos de edificios de la vecina ciudad de Úbeda, presumiblemente de la misma formación geológica.

La tabla II muestra la estimación de contenidos de especies minerales obtenida del difractograma de rayos- $X$
The average yearly rainfall is $300 \mathrm{l} / \mathrm{m}^{2}$. March is the month with the highest pluviometry, with $80 \mathrm{l} / \mathrm{m}^{2}$, while july is less than $5 \mathrm{l} / \mathrm{m}^{2}$. The maximum rainfall in 24 hours is of $100 \mathrm{l} / \mathrm{m}^{2}$. From 1 to 5 snowfall days a year are recoried.

The dominating winds during the year are south-western (SW), of weak character. The average yearly speed is $10 \mathrm{~km} / \mathrm{h}$, always under $50 \mathrm{~km} / \mathrm{h}$, and $75 \%$ of the times, under $20 \mathrm{~km} / \mathrm{h}$. Sun radiation is $4,75-5 \mathrm{kw} / \mathrm{m}^{2}$ day. $2.990 \mathrm{~h}$ of yearly sunshine are registered, the maximum in july $(390 \mathrm{~h})$ and the minimum in january $(160 \mathrm{~h})$. The average yearly potential evaporation (Thornthwaite's formula) is $950 \mathrm{l} / \mathrm{m}^{2}$.

\subsection{Pollution}

Numeric data about atmospherical contamination are not available, but taking into account the urban characteristics of the zone, the ground topography (monument in a high, windy zone) and the little traffic, it is logic to suppose that acid contamination, to which this stone type is highly sensitive, is little significant.

\subsection{Underground}

It could be thought that the freatic layer was not an hydric contribution source, because of the topographic situation above mentioned. Nevertheless, some parts of the building can be observed where the rising damp is serious.

\section{PETROUS MATERIALS}

Two kinds of stone have been mainly employed for the construction of this building, one "franca", of easy working and medium porosity, and the other "viva", hard, more compact and dense. Being both ochre yellowish coloured, they tend to get darker in meteorization, but in general "franca" becomes brown and "viva" reaches a greyish tone. Another type can be found, with layers of different colours, blue ones with slaty aspect and other yellow ones, which are called "jabaluna" in this zone. These stone types are under study in this project through different samples taken from the monument (Table I). $E$. Sebastian (1995) typified some samples from Atalayon quarries, located on the south of the town, as $R$. Villegas did with other samples obtained from demolished buildings of the neighbour town Úbeda, which are probably of the same geological formation.

Table II shows an estimation of the mineral species content, which has been obtained from the K-rays power 


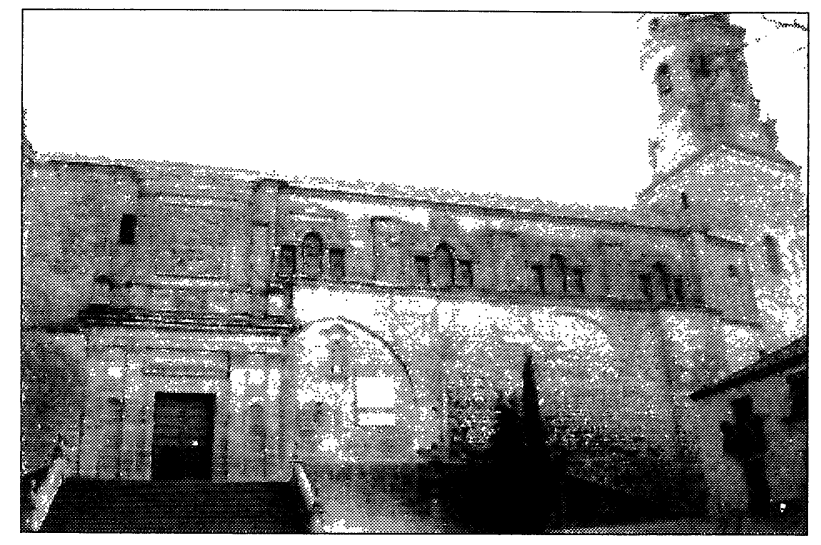

a) Vista general. Agentes biológicos.

a) General view. Biological agents.

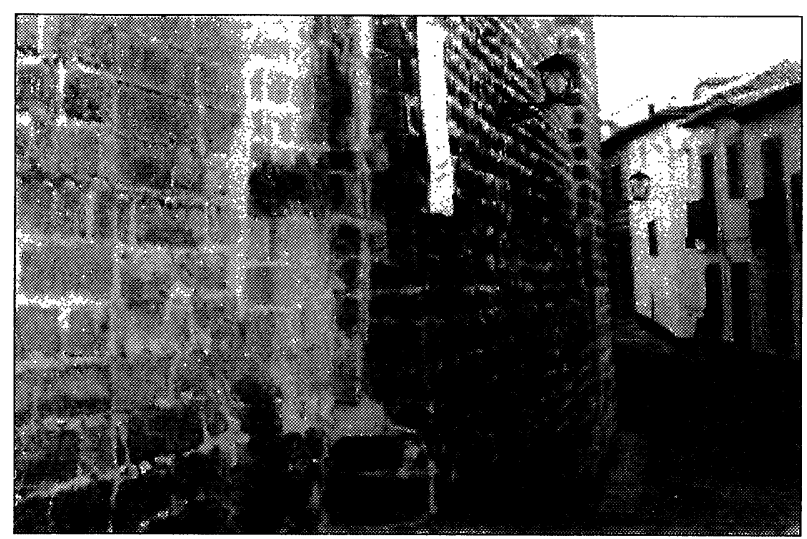

c) Humedad ascendente. Reparaciones.

c) Rising damp. Repairs.

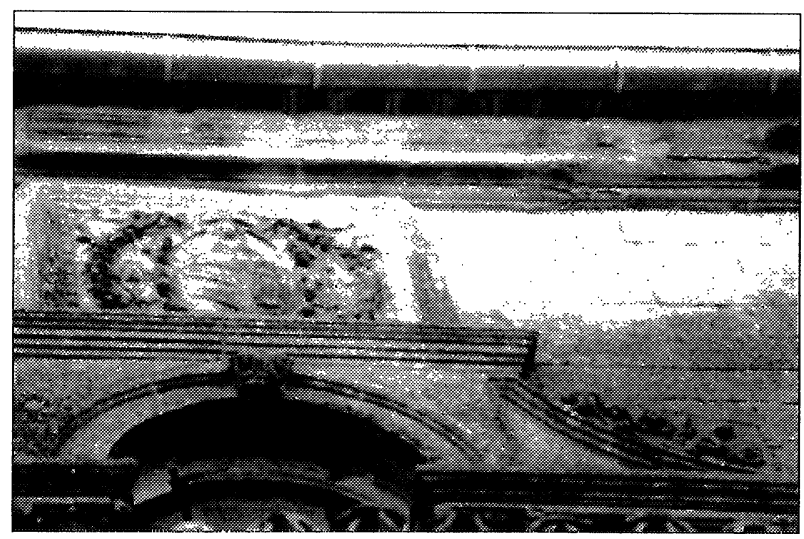

e) Arenizaciones y disyunciones de placas.

e) Grain disgregations and contour spalling.

Figura 1.- Fachada Principal. Catedral de Baeza.

Figure I.- Main Façade. Cathedral of Baeza.

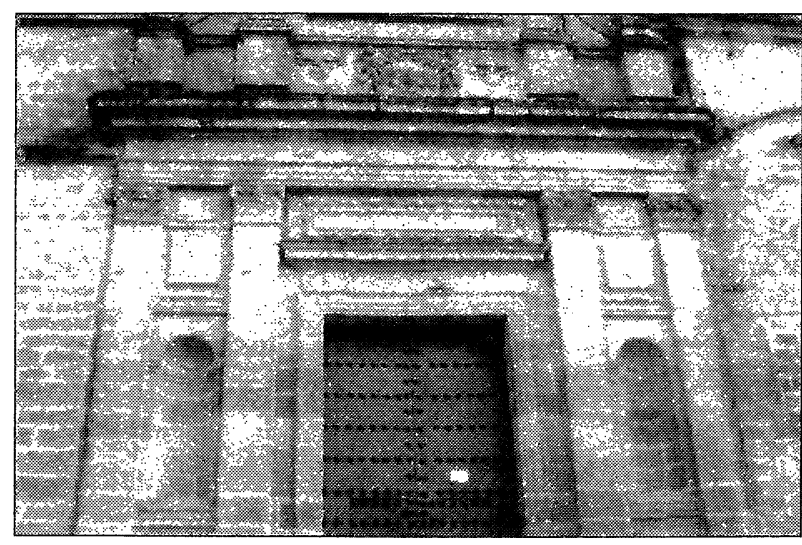

b) Pátina en diversos litotipos. Fractura.

b) Patina in different lytotypes. Fracture.

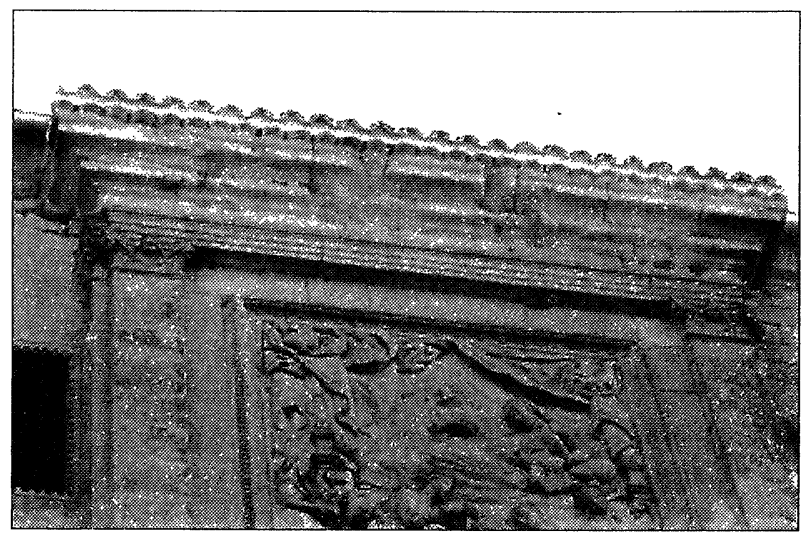

d) Arenizaciones en piedra franca de cornisas.

d) Grain disgregation franca stone of cornices.

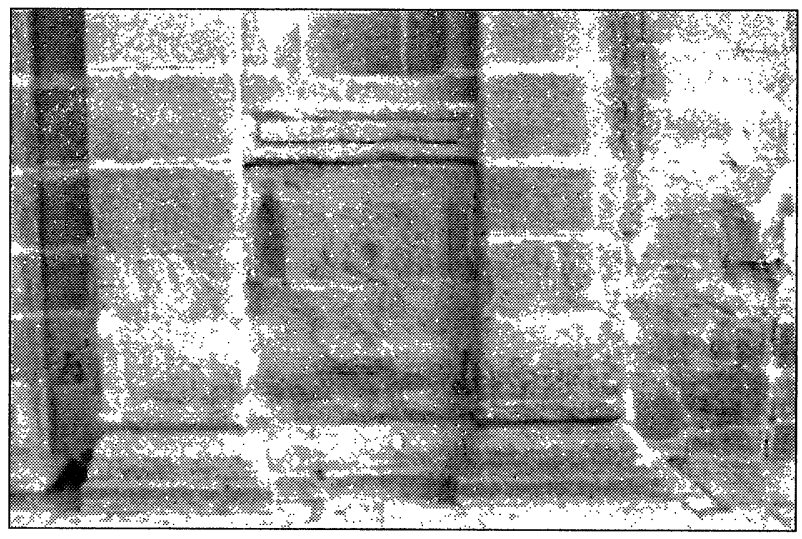

f) Picado general y fragmentaciones en bordes.

f) General pitting and spalling on edges. 
TABLA II (TABLE II)

Estimación cie contenidos de especies minerales (difracción de R-X)

(Estimation of the mineral species content (X-ray power diffraction))

\begin{tabular}{||l|c|c|c|c|c|c|c|c|c|c|c|c|c|c||}
\hline $\begin{array}{l}\text { Muestra } \\
\text { (Sample) }\end{array}$ & 1 & 2 & 3 & 4 & 5 & 6 & 7 & 8 & 9 & 10 & 11 & 12 & 13 & 14 \\
\hline $\begin{array}{l}\text { Calcita (\%) } \\
\text { (Calcite) }\end{array}$ & 48 & 38 & 27 & 34 & 43 & 16 & 43 & 48 & 11 & 50 & 22 & 19 & 45 & 62 \\
\hline $\begin{array}{l}\text { Cuarzo (\%) } \\
\text { (Quartz) }\end{array}$ & 27 & 32 & 31 & 15 & 29 & 9 & 26 & 33 & 23 & 27 & 51 & 52 & 18 & 37 \\
\hline $\begin{array}{l}\text { Dolomita (\%) } \\
\text { (Dolomite) }\end{array}$ & 18 & 21 & 39 & 51 & 23 & 69 & 25 & 19 & 61 & 7 & 19 & 30 & 36 & \\
\hline $\begin{array}{l}\text { Feldespato (\%) } \\
\text { (Feld'spar) }\end{array}$ & 6 & 7 & 5 & & 5 & 6 & & & 5 & 7 & 7 & & & \\
\hline
\end{tabular}

de varias muestras. Se ha empleado el Difractómetro Phillips PW 1710 del Departamento de Mineralogía de la Universidad de Granada, equipado con una rendija automática. Análisis cualitativo: la mineralogía íntegra de cada una de las fracciones de las distintas muestras se ha obtenido mediante el método de polvo cristalino. Análisis semicuantitativo: en los difractogramas de la muestra total se han medido las áreas de las reflexiones más importantes de cada uno de los minerales, utilizando en la cuantificación los poderes reflectantes calculados para el equipo utilizado.

Los contenidos de calcita son bastante inferiores a los valores de carbonato cálcico ofrecidos por Sebastián (60-75\%) y por Villegas (59-68\%), lo cual no sería extraño dado que, en este caso, se trata de muestras obtenidas de la superficie alterada de la piedra, pero los contenidos de dolomita son muy grandes mientras que en el caso de Villegas las muestras no presentan ningún carácter dolomítico. Por tanto, dentro de la misma zona parece ser que existe gran heterogeneidad en la composición química de las piedras.

La Tabla III muestra algunos resultados de la porosimetría realizada por intrusión de mercurio. Las muestras 3 y 4 fueron catalogadas macroscópicamente al ser obtenidas como de piedra viva, pero sus porosidades $(\sim 10 \%)$ son mayores que las ofrecidas por Sebastián para las muestras de cantera (4\%), lo cual manifiesta la alteración sufrida en el monumento. Al comparar entre sí ambas, puede observarse que la 3 , que en el monumento se encontraba más alterada que la 4, presenta mayor volumen relativo en el rango de los macroporos y menor en el de los microporos; la 3 tiene su radio dominante en $13,96 \mu \mathrm{m}(24,6 \%)$ mientras que en la 4 es $0,91 \mu \mathrm{m}(26 \%)$. Las muestras 12 y 13 , correspondientes a la variedad franca y en estado de mayor degradación en el monumento, presentan diffractogram of some samples. Phillips PW 1710 Diffractometer from the Mineralogy Department of Granada University has been used. It is equipped with automatic aperture. "Qualitative analysis": the integral mineralogy of each of the samples fractions have been obtained through the crystalline power method. "Semiquantitative analysis": the most important reflection areas of each mineral have been measured in the diffractograms of the total sample, using for this quantification the reflecting powers calculated for the equip in use.

The contents of limestone are rather lower than the values of calcic carbonate given by Sebastian (60-75\%) and by Villegas (59-68\%), which would not be estrange taking into account that in this case the samples were obtained from the altered surface of the stone, but the contents of dolomite are very great while Villegas samples do not present any dolomitic character. Thus, a great heterogeneity of the stones chemical composition seems to exist within the same zone.

Table III shows some results of the porosimetry carried out through mercury intrusion. Samples 3 and 4 were catalogued macroscopically, as they were obtained as viva stone, but their porosities ( 10\%) are higher than the ones that Sebastián gave for the quarry samples (4\%), which shows the deterioration suffered by the monument. When comparing both samples, it can be observed that number 3, more deteriorated than 4, presents a higher relative volume in the macropores range, and lower in the micropores one; sample 3 dominant radium is $13,96 \mu \mathrm{m}(24,6 \%)$, while sample 4 is $0,91 \mu \mathrm{m}(26 \%)$. Samples 12 and 13, corresponding to franca variety, more degraded in the monument, present higher rates of porosity $(28,94 \%$ and $24,82 \%)$, 
Algunos valores obtenidos en la porosimetría por intrusión de mercurio (Some values obtained in the porosimetry by mercury intrusion)

\begin{tabular}{|c|c|c|c|c|}
\hline $\begin{array}{l}\text { Muestra } \\
\text { (Sample) }\end{array}$ & 3 & 4 & 12 & 13 \\
\hline $\begin{array}{l}\text { Densidad ap. (g/ml) } \\
\text { (Density bu.) }\end{array}$ & 2 & 1,97 & 1,75 & 1,76 \\
\hline $\begin{array}{l}\text { Porosidad (\%) } \\
\text { (Porosity) }\end{array}$ & 9,51 & 9,54 & 28,94 & 24,82 \\
\hline $\begin{array}{l}\text { Radio medio }(\mu \mathrm{m}) \\
\text { (Average radius) }\end{array}$ & 12,44 & 11,53 & 14,96 & 21,45 \\
\hline $\begin{array}{l}\text { Radio dominante ( } \mu \mathrm{m}) \\
\text { (Dominant radius) } \\
\text { Volumen (\%) } \\
\text { (Volume) }\end{array}$ & $\begin{array}{c}13,96 \\
24,6\end{array}$ & $\begin{array}{l}0,91 \\
26,0\end{array}$ & $\begin{array}{c}16,93 \\
24,1\end{array}$ & $\begin{array}{c}21,68 \\
17,9\end{array}$ \\
\hline $\begin{array}{l}\text { Macroporos ( } \mu \mathrm{m}) \\
\text { (Macropores) } \\
\text { Volumen (\%) } \\
\text { (Volume) }\end{array}$ & $\begin{array}{c}10,92-17,31 \\
47,8\end{array}$ & $\begin{array}{c}11,97-21,01 \\
41,2\end{array}$ & $\begin{array}{c}11,97-21,01 \\
62,6\end{array}$ & $\begin{array}{c}14,53-27,93 \\
67,2\end{array}$ \\
\hline $\begin{array}{l}\text { Microporos ( } \mu \mathrm{m}) \\
\text { (Micropores) } \\
\text { Volumen (\%) } \\
\text { (Volume) }\end{array}$ & $\begin{array}{c}0,60-1,82 \\
23,0\end{array}$ & $\begin{array}{c}0,45-1,82 \\
31,8\end{array}$ & $\begin{array}{c}0,36-1,80 \\
14,9\end{array}$ & $\begin{array}{c}0,61-1,81 \\
11,4\end{array}$ \\
\hline
\end{tabular}

mayores porosidades $(28,94 \%$ y $24,82 \%)$ y distribuidas éstas principalmente en el rango de los macroporos $(62,6 \%$ y $67,2 \%)$.

\section{MORFOLOGÍA MACROSCÓPICA DE LAS ALTERACIONES}

A continuación se presenta un estudio de las alteraciones para cada una de las fachadas, comenzando por la Principal, orientada al N-NO (por comodidad, a partir de ahora se designará esta orientación como norte). Dentro de cada fachada, se hacen unas consideraciones previas acerca de los materiales de construcción empleados, clima, urbanismo, ambiente, agentes biológicos y comportamiento mecánico y estructural, lo cual orienta acerca de los factores de alteración que pueden intervenir, describiéndose, a continuación, los indicadores visuales de alteración, siguiendo el orden: modificaciones superficiales, disyunciones, deformaciones, eliminaciones de materia y rupturas, y empleando para ello una terminología sistematizada. (Alcalde, 1990 y Martín, 1990). mainly distributed within the macropores range $(62,6 \%$ and $67,2 \%)$.

\section{MACROSCOPICAL MORPHOLOGY OF THE DETERIORATIONS}

A description of the alterations of each façade will be made, starting with the Main one, $\mathrm{N}-\mathrm{NW}$ oriented (for convenience, this orientation will be referred to as North from now on). For each façade some previous considerations will be made, about the employed construction materials, climate, urbanism, environment, biological agents, and structural and mechanic behaviour. These references may serve as a guide of possible deterioration factors, and visual indicators of deterioration will be described in the following order: superficial modifications, disjunctions, deformations, eliminations of material and ruptures. The systematized terms by Alcalde and Martin (1990) will be used for the presentation of cited elements under study. 


\subsection{Fachada Principal}

Está orientada al norte, precedida por la amplia plaza de Santa María, con poco tráfico rodado. Una cierta pendiente hace que el templo quede en alto. Una escalinata da acceso a la portada y en el lado izquierdo tiene adosado un palacio (Casas Consistoriales Altas). A la derecha se alza una robusta torre, con dos partes perfectamente diferenciadas, la superior claramente más moderna.

Como en toda la edificación, existe falta de cohesión entre las diferentes fábricas. Los faldones de cubierta de la nave principal aparecen ligeramente alabeados y los planos superiores de las cornisas muestran numerosas alteraciones. En la zona occidental del muro perimetral, pueden distinguirse tres sillerias diferentes y la falta de traba entre sus fábricas ha derivado en importantes fisuras y en varias reparaciones que han resultado ineficaces. En el muro más antiguo hay algunos huecos góticos que han sido cegados. Este muro muestra un importante desplome de alrededor de 0,6 metros en su parte baja exterior; no obstante, en el interior muestra una perfecta verticalidad. Este muro es de la Catedral original del siglo XIII, ha sufrido los efectos del terremoto de 1567 y ha sido reparado mediante su recrecido. Los sillares centrales del falso dintel muestran desplazamientos que hacen que la entrada principal sufra un importante descuelgue, causa de la fragmentación del estribo y de algunas fracturas sobre ellos.

La esquina de la cabecera muestra una importante reparación. Los sillares de una banda vertical de la fábrica, de aproximadamente un metro de anchura, han sido tomados de nuevo con mortero de cal. En 1980, algunos materiales de cubierta fueron sustituidos en la cabecera de la Catedral, y esta esquin de la cabecera, con mayores grietas, fue atada con un zuncho de hormigón.

Dada su orientación, es una fachada umbria por lo que e' desarrollo de agentes biológicos es abundante. Los líquenes cubren prácticamente toda la fachada, de forma más derasa en las esquinas de las pilastras, pináculos, etc., orientadas hacia poniente. Este efecto de la orientación se hace especialmente patents en el musgo gue crece en las cornisas de la torre, mucho más abundante en esa dirección. Plantas suneriores crecen en muchos ingares, cornisas, rincones, ec., y resula llamativa su prohreración en on lienzo adyacente a la tore (Figura 1a).

Bi sistema general de recogida de aguas pluviales ha sido hasta hace poco bastante defichente.

\subsection{Main Façade}

It is north oriented, facing Santa Maria great square, with little traffic. A certain slope keeps the temple high. A front steps gives access to the portal, and a palace (High Consistorial Houses) is leaned against the left side. A robust tower stands up on the right side, with two different parts, the upper one clearly more modern than the lower one.

Lack of masonry cohesion appears as a constant feature in the entire building. The roof inclined planes of the main nave appear to be slightly warped and the cornices upper planes show several alterations. In the western zone of the perimeter wall, three different stone works can be distinguished; the lack of ties among the various masonries has derived into important fissures and into a series of repairs which have resulted inefficient. Some gothic openings have been closed up on the oldest wall, which shows an important overhang of around 0,6 metres in its external lower part, nevertheless the inside presents a perfect verticality. This wall belongs to the original Cathedral (XIII century), and it suffered the earthquake effects in 1567 , being repaired through increasing later. The central ashlars of the false lintel show a general displacement provoking a serious lowering on the main door, as a consequence of the buttress fragmentation and some fractures on the ashlars.

The head corner shows an important repair. The ashlars of one of the masonry vertical bands, approximately one metre wide, have been joined again with a lime mortar. In 1980 some roof cover materials were substituted on the head zones of the Cathedral, and this head corner with greater crevices was tacked with a concrete strap.

Due to its orientation, this is a shady façade, which helps the biological agents development. Lichens cover almost the whole façade, specially the west-oriented zones such as the comer of some pilasters, pinnacies, eic. The orientation effect proves to be even more salient in the tower cornices, whose north-oriented zones are much more covered with musk. Superior plants grow in many places, comices, comers, ete and they proliferate specially in the tower adjoining streth (Figure Ia).

The general rain water draning system has ben full deficient until lithe time ago. 


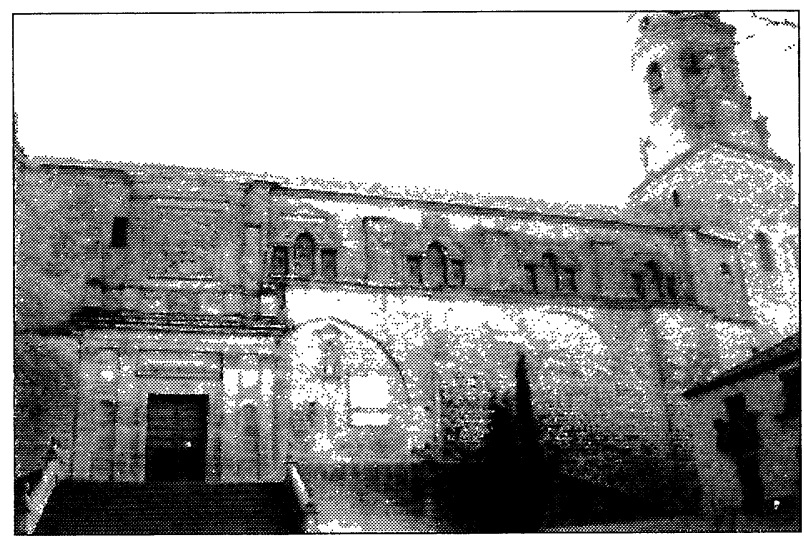

a) Vista general. Agentes biológicos.

a) General view. Biological agents.

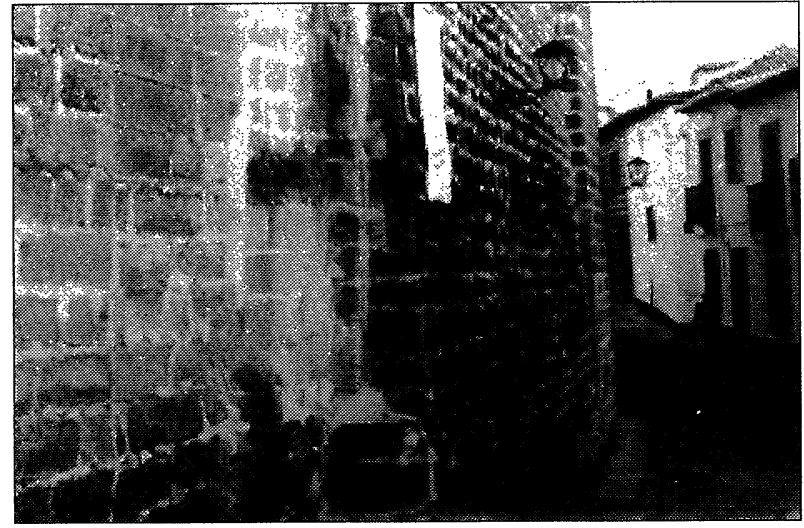

c) Humedad ascendente. Reparaciones.

c) Rising damp. Repairs.

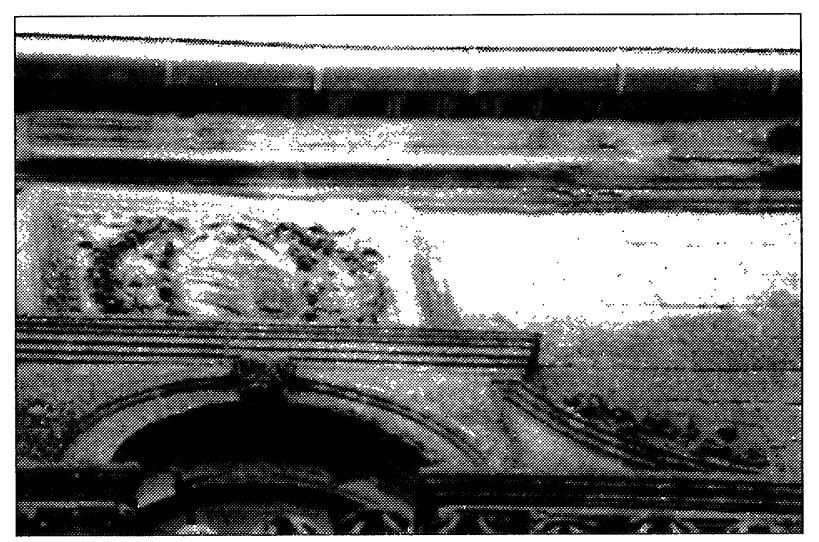

e) Arenizaciones y disyunciones de placas.

e) Grain disgregations and contour spalling.

Figura 1.- Fachada Principal. Catedral de Baeza

Figure 1.- Main Façade. Cathedral of Baeza.

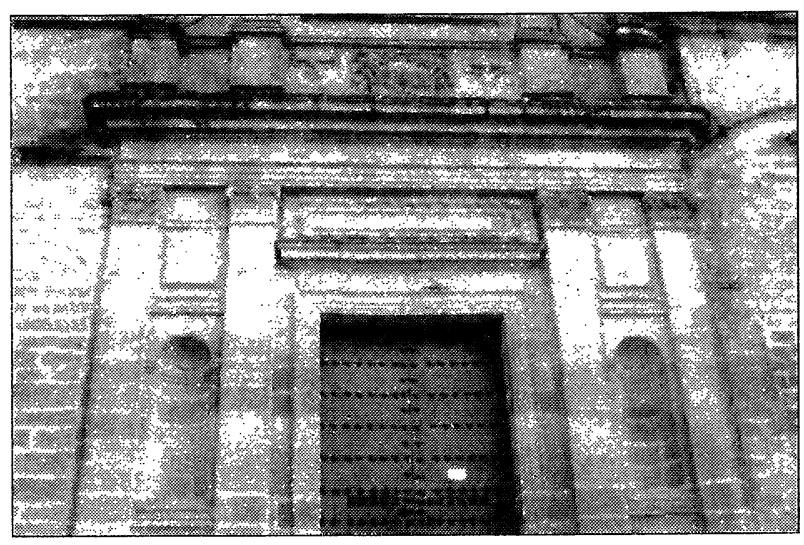

b) Pátina en diversos litotipos. Fractura.

b) Patina in different lytotypes. Fracture.

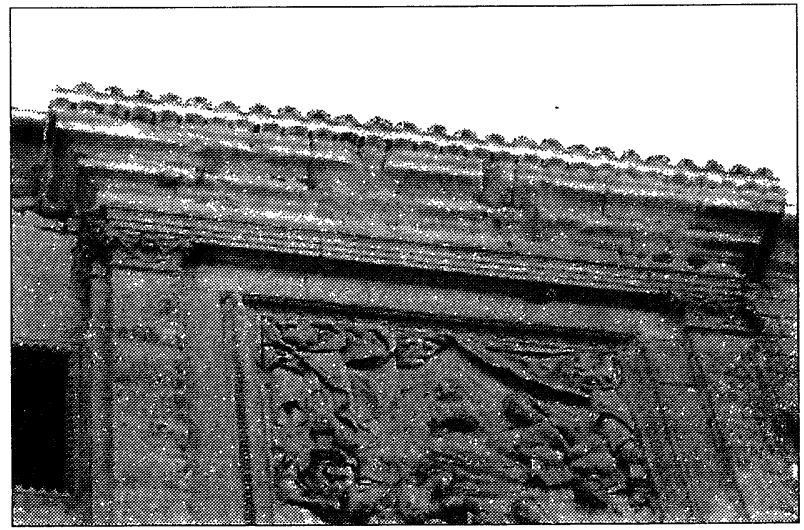

d) Arenizaciones en piedra franca de cornisas.

d) Grain disgregation franca stone of cornices.

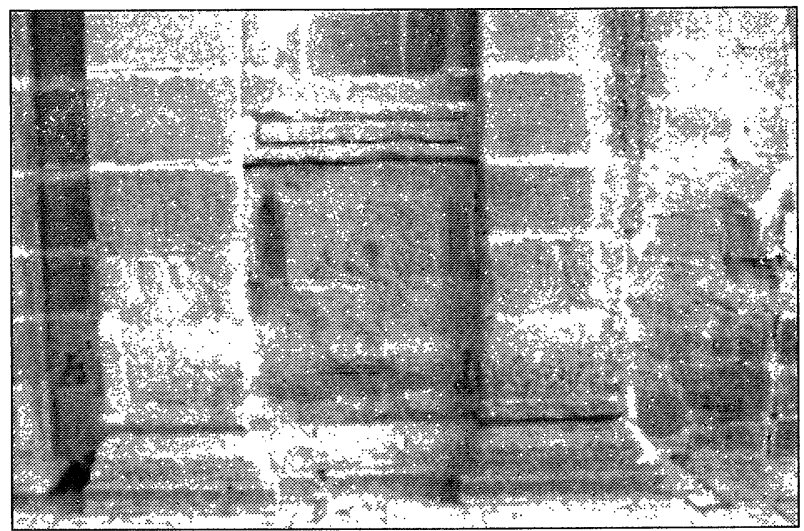

f) Picado general y fragmentaciones en bordes.

f) General pitting and spalling on edges. 
Los dos tipos de piedra que, de forma mayoritaria, han sido empleados en su construcción, se distinguen claramente en esta fachada por la tonalidad de su pátina, una, grisácea, la más abundante, y otra, más amarilla o marrón (franca) en la portada y algunas cornisas (Figura 1b). Al pie de la torre hay unos fustes de mármol empotrados en las aristas de la misma. Otros materiales existentes son aquéllos empleados en tareas de reparación como morteros, en ocasiones de cemento portland, cascotes, ladrillos, etc. (Figura 1c). La cúpula de la torre parece ser de cemento portland.

Los indicadores de alteración más graves son las arenizaciones, que afectan en mayor grado a la piedra amarilla, sobre todo en las cornisas donde la pérdida de materia a veces es tan abundante que los elementos se encuentran en estado de ruina (Figura 1d). Algunas superficies de cornisas más resistentes muestran cómo estas arenizaciones han sido precedidas por disyunciones, en las que las costras superficiales endurecidas se desprenden en forma de placas, continuando, después, el proceso de arenización (Figura 1e).

El cuerpo inferior de la portada, también de piedra franca, presenta a mitad de su altura una franja horizontal de pátina gris, de no fácil explicación (Figura 1b). Las zonas bajas, además de arenizaciones presentan un picado general en toda la superficie y numerosas fragmentaciones en los labrados más angulosos, como molduras, aristas, etc. (Figura 1f). Sin embargo, las pechinas de las hornacinas y los capiteles de las pilastras se conservan bien. En las bases de estas pilastras pueden verse algunas vermiculaciones. En el dintel se observa un desplazamiento de bloques, que, quizás, sea el origen de la fractura que presenta la inscripción de consagración del templo (Figura 1b). Este dintel muestra también la pérdida de una gran placa.

Contrasta el buen estado de la piedra con pátina gris, a la que, afortunadamente, pertenece el gran relieve de la Natividad de la Virgen del segundo cuerpo de la portada, bien conservado, con sólo bioalteraciones cromáticas debidas a líquenes (Figura 1d). Igualmente bien conservada la estatua de la Virgen que hay debajo del arco gótico y los escudos y lápida del pie de la torre, salvo la pérdida de algunos de los caracteres góticos de las inscripciones y pequeñas fragmentaciones de las molduras que hacen de marcos.

Las cornisas de la portada tienen abundante desarrollo de agentes biológicos que llegan a plantas superiores, y presenta numerosas fracturas y fragmentaciones de las aristas (Figura 1b). La humedad ascendente ha
In this façade, the two most common types of stone are easily distinguishable for their patina tone; the most abundant one is greyish, and the other (franca) tends to yellow or brown in the portal and in some cornices (Figure 1b). Some marble fusts appear at the tower foot edges. The tower dome seems to be made of portland cement.

The most serious deterioration indicators are grain disgregations, which affect yellow stone especially, mainly in cornices, where the huge amount material loss sometimes leads to state of ruins (Figure 1d). Some more resistant cornices surfaces show how grain disgregations have been preceded by disjunctions, in which hardened superficial crusts fall off in form of plaques, coming later the process of grain disgregation (Figure 1e).

The lower body of the portal, made of franca stone too, presents horizontal strip of grey patina at middle height, which is not easily explainable (Figure $1 b$ ). Besides disgregations, the lower zones present a general pitting on all the surface and numerous spallings in the most angular carved stones, as moulding, edges, etc (Figure 1f). Nevertheless, the niches pendentives and the pilaster capitals are well conserved. In the bases of these pilasters, some vermiculations can be seen. An ashlar displacement is observed in the lintel, which may be the origin of the cracking that the temple consecration inscription presents (Figure 1b). This lintel also shows the loss of a large plaque.

In contrast, grey patina stones appear to remain in good state. Fortunatelly the Virgin Nativity embossment of the second portal body belongs to that stone type, and it is well conserved, only with some chromatic bioalterations due to lichens (Figure 1d). The Virgin statue under the gothic arch and the escutcheons and the stone tablet of the tower foot keep a good state as well, except for the loss of some of the gothic characters in the inscriptions and small spallings in the frames mouldings.

The portal cornices have broadly developed biological agents, appearing even superior plants, and their edges present numerous cracks and spalling (Figure lb). 


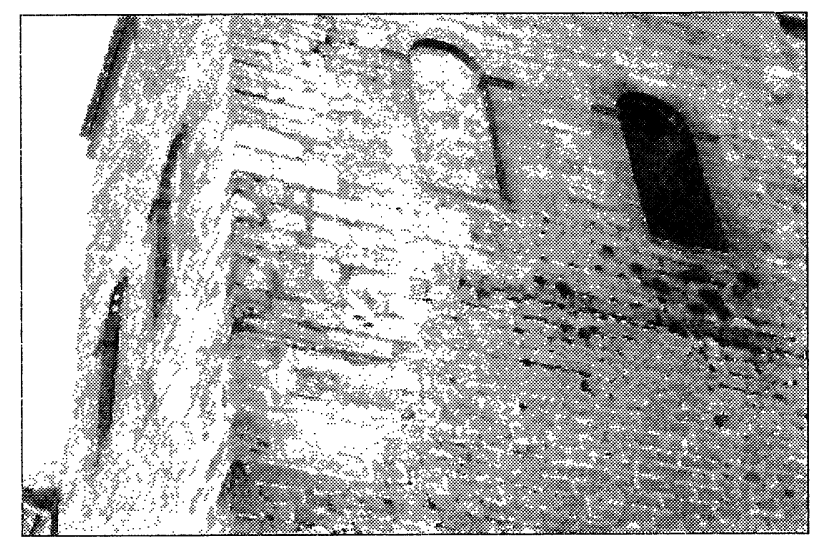

a) Liquenes y plantas superiores. Fisuras.

a) Lichens and vascular plants. Fissures.

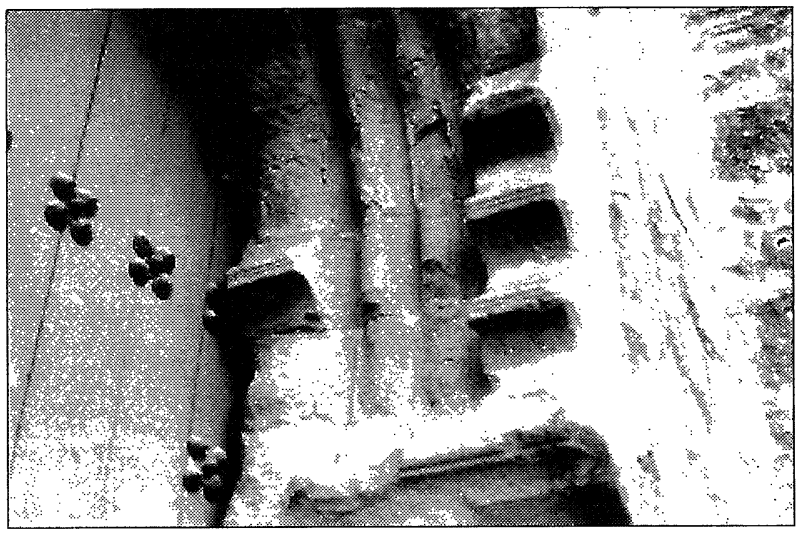

c) Disyunciones y fragmentaciones.

c) disjunctions and spalling

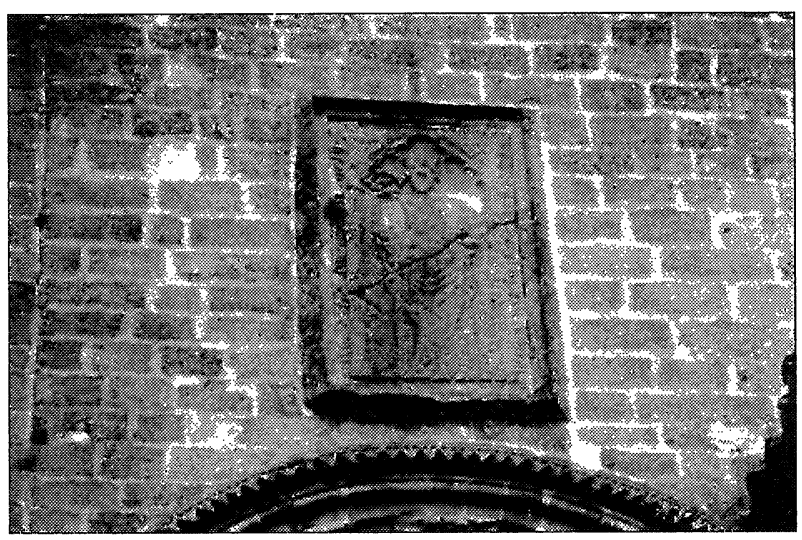

e)Cromatización y fisura en lápidae.

e) Chromatization and fissure on stone tablet.

Figura 2.-Fachada Occidental. Catedral de Baeza.

Figure 2.- West Façade. Cathedral of Baeza.

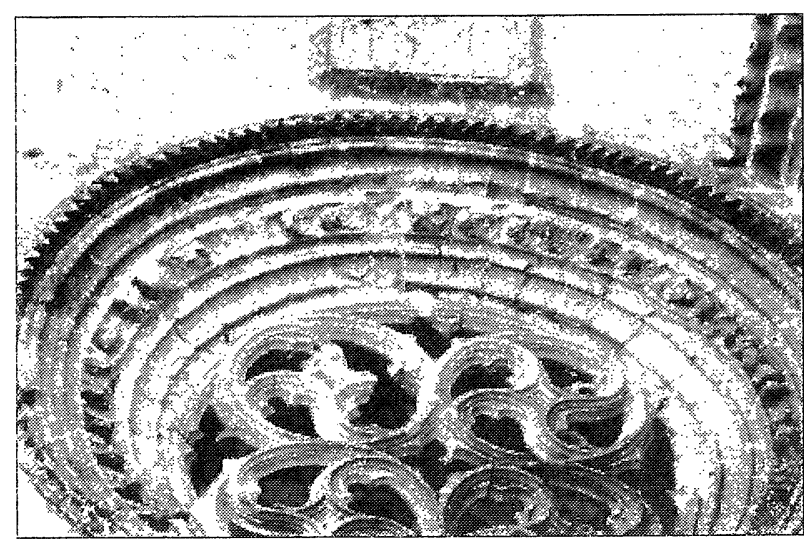

b) Mayor degradación en la piedra franca.

b) larger weathering on franca stone.

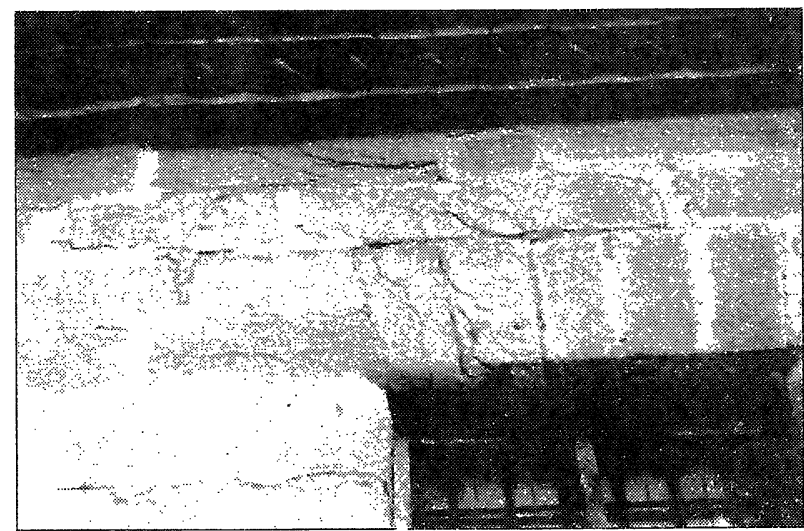

d) Exfoliaciones

d) Peeling.

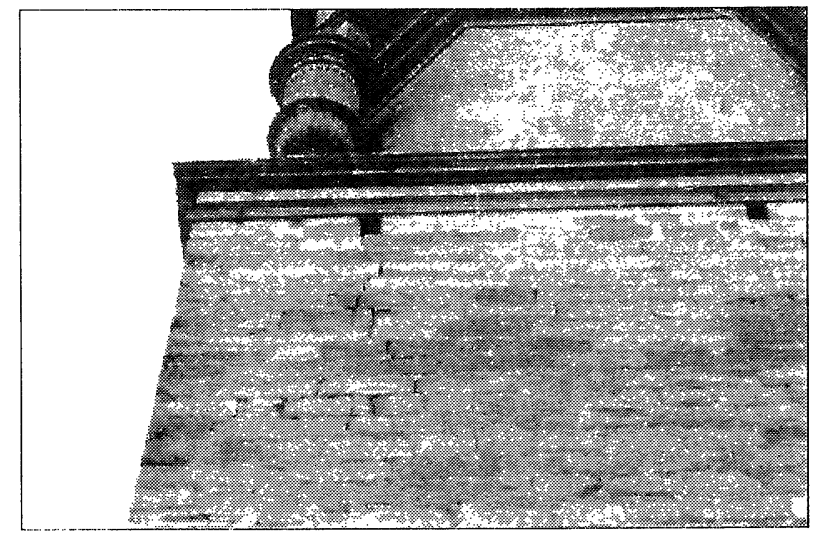

f) Fisuras por cargas mecánicas

f) Fissures due to mechanical stresses. 
provocado arenizaciones en las zonas bajas, más graves en los bloques comprendidos entre la tercera y sexta hilera de sillares en el lienzo que queda a la derecha de la portada (Figura 1c). Aunque sólo tiene carácter anecdótico, queda por mencionar que el fuste empotrado al pie de la torre presenta excavación.

\subsection{Fachada Occidental}

Es una fachada de trazado muy irregular, con volúmenes adosados. Esta fachada contiene los elementos más antiguos de la Catedral. De piedra amarilla es el rosetón gótico y las cornisas del volumen correspondiente a la capilla de los Viedmas. La recorre una calle estrecha, con escaso tráfico, de forma que las zonas bajas permanecen siempre umbrías. No hay signos de humedad ascendente de importancia, excepto en los zócalos del volumen situado más al sur, Capilla de los Viedmas. En los muros del interior de esta Capilla se aprecian grandes manchas de humedad con eflorescencias de sales. En las superficies exteriores de esta fachada orientadas al norte hay abundancia de líquenes. Las plantas superiores crecen en la pared de la torre a partir de una altura en que reciben el sol (Figura 2a).

El primer cuerpo de la torre muestra grietas y fisuras en su zona superior, que crecen en importancia en ambas caras que concurren en la esquina norte. Las direcciones de las fisuras son principalmente verticales, aunque tienen recorridos sinuosos a través de los sillares del muro. Éste debe ser un antiguo problema mecánico de la torre, porque toda la esquina afectada está cegada, incluidos sendos huecos (Figura 2a). •

La última intervención realizada en la Catedral ha sido una urgente reconstrucción de la cubierta de la Capilla de los Viedmas, que de repente colapsó. Los elementos estructurales dañados han sido reemplazados y el tejado se ha trabado bien a la fábrica mediante un tradicional mortero de cal. El lienzo que queda al sur de este volumen es de piedra más reciente, de color claro, y con morfología de alteraciones diferente al resto. Existen sustituciones de piedra de restauraciones fácilmente localizables por la ausencia de pátina, por ejemplo, en las zonas altas de los paramentos. También se observa cierta heterogeneidad de materiales en la torre. Dentro de los morteros empleados, no deja de tener presencia el cemento portland.

La pérdida de materia por arenización es mayor en la piedra amarilla, como puede verse en el rosetón, en el que algunos de los elementos decorativos, hojas y caras, se han perdido, mientras que en la moldura exterior sólo han desaparecido algunas de las puntas de diamante, por fragmentación (figura $2 \mathrm{~b}$ ). El intradós
Rising humidity has provoked grain disgregation in the lower zones, more serious in the blocks located between the third and sixth ashlars courses of the stretch on the right side of the portal (Figure 1c). As an anecdotical remark, it could be mentioned that the fust built in the towers foot presents excavation.

\subsection{Western Façade}

It is very irregularly traced, with volumes leaned ones against the others. This façade contains the most ancient elements in the Cathedral. The gothic rose window and the Viedmas Chapel cornices are made of yellow stone. The west façade is placed in a narrow street with little traffic, so that the lower zones always remain shady. No sign appears of remarkable rising damp, except for the socles of the most southern volume, the Viedmas Chapel. Great spots of humidity with salt efflorescences can be observed on this Chapel inner walls. The north oriented exterior surfaces present great abundance of lichens. Superior plants grow on the sunbaked zones of the tower wall (Figure 2a).

The upper zone of the first body of the tower show crevices and fissures, which become more important in both sides concurring in the northern corner. The fissures directions are mainly vertical, although they go through the masonry ashlars sinuously. This must be an old mechanical problem of the tower, because the whole affected corner has been walled up, including both cavities (Figure 2a).

The most recent intervention undergone by the Cathedral consisted of an urgent replacement of the Viedmas Chapel roofing, which had suddenly collapsed. The damaged structural elements have been replaced and the roof has been leaned to the masonry with a traditional lime mortar. The stretch located on the southern side of this volume is more recent, it is light coloured and its morphology presents deteriorations differing from the rest. Various stone substitutions from past restorations are easily recognizable by lack of patina, for instance, in the paraments higher zones. This material heterogeneity is also observed in the tower. Among the different employed mortars, portland cement is also used.

Material loss because of grain disgregations appears to be more common in yellow stone. For instance, the rose window has lost some of its decorative elements, such as leaves and faces, while in the external mouldings, only some of the diamond points have disappeared because of fragmentation (Figure $2 b$ ). 
del arco mudéjar de la Puerta de la Luna está muy degradado por arenizaciones, fragmentaciones $y$ disyunciones de placas (Figura $2 \mathrm{c}$ ). La piedra nueva antes mencionada se altera mediante exfoliaciones, indicador que no es corriente en la catedral (Figura 2d). La lápida situada sobre el rosetón presenta cierta disgregación con leve pérdida de relieve, y una gran fisura (Figura 2e). En el volumen situado más al sur y en la torre aparecen otras fisuras producidas por cargas o por alguno de los terremotos que ha afectado al monumento (Figura 2f). Las cornisas presentan pequeñas fragmentaciones, y en la esquina que dobla hacia la fachada sur hay excoriaciones. En el interior de la Capilla de los Viedmas, pueden ser apreciadas en los muros importantes manchas de humedad y precipitaciones de sales

\subsection{Fachada Meridional}

A pesar de su orientación al sur está poco soleada en sus volúmenes bajos, ya que la recorre una calle angosta, una de las más típicas y bellas de la ciudad (Figura 3a). En ella se abre la Puerta del Perdón (Figura 3b). Esta zona de la edificación es la más antigua y dañada, mostrando sus fábricas desconectadas, combadas y desmembradas. Estos signos se enfatizan al acercarse a la Puerta del Perdón, la cual está en pie gracias al cuerpo de conexión con forma de arco. También, las diferentes fábricas que forman el muro con esta orientación muestran fisuras debidas a cargas estructurales .

La edificación de la esquina oeste ha sido reparada en su tejado y pared lateral. Sin embargo, muestra algunas fisuras verticales en sus fábricas. Caminando a través de la estrecha calle adyacente a la Catedral, un generalizado problema de humedad ascendente $y$ descomposición de muros puede ser apreciado en las sucesivas fábricas (Figura 3a). Los agentes biológicos abundan más en estas zonas más umbrías y húmedas, debajo de las cornisas y en las esquinas de los contrafuertes.

La esquina del muro de la Sacristía, al final de la estrecha calle, presenta algunas fisuras verticales en sus fábricas. Algunas se localizan en las zonas altas, pero es de destacar una, situada cerca de la esquina, que se aproxima al suelo y que es más ancha en su desarrollo. La Capilla de los Dolores constituye un caso singular de fábricas con falta de trabazón, porque es más una apertura lateral en un muro al que se añade una construcción trasera y desconectada del mismo. En su interior, pueden ser apreciados todo tipo de problemas de humedades (Figura 3b).

La piedra estructural presenta en general un labrado muy tosco, excepto en los conjuntos de ventanas. El
The mudejar arch intrados of the Moon Door is very affected by grain disgregations, spalling and contour scalling (Figure 2c). The new stone, above mentioned, is deteriorated by peelings, which is not very common in the cathedral (Figure 2d). The gravestone located over the rose window presents some disgregation with slight relief loss and a great fissure (Figure 2e). On the most southern volume and in the tower, some other fissures appear, which are caused by loads or by some of the earthquakes that have affected the monument (Figure 2f). The cornices present small spalling, and various instances of excoriations appear in the corner turning towards the southern façade. Serious moisture tarnishes and salts precipitations can be appreciate over the inside walls of the Viedmas Chapel.

\subsection{Southern Façade}

In spite of its southern orientation, the lower volumes of this façade are little sunbaked, because this side of the building faces a narrow street, being one of the most beautiful and most typical streets in the town (Figure 3a). Here Forgiveness Door is located (Figure $3 b)$. The southern façade is the oldest and most damaged part of the building, showing unconnected, sagged, dismembered masonries, particularly when referring to Forgiveness Door, still standing up thanks to the arch shaped connection body. Also, the different masonries in this wall show a series of fissures caused by mechanical or structural loadings.

The western corner edification has been repaired in its roof and lateral wall, however, some vertical fissures remain in the masonries. Walking along the Cathedral narrow front streets, generalized problems of rising damp and wall decomposition can be appreciated in the successive masonries (Figure 3a). Biological agents are more abundant in this damp and shady zones, under cornices and in the abutments corners.

The Sacristy wall corner, at the end of the narrow street, present vertical fissures in its masonries. Some of them are located in the highest zones, but the most remarkable one is near the corner, approaching to the ground, growing wider as it develops. Dolores Chapel constitutes a special case of lack of masonry bracing, because it consists of a lateral opening on a wall where an unconnected building has been attached. Inside, all kinds of moisture problems can be found (Figure $3 b$ ).

In general, the stone work appears to be very roughly carved, except for the groups of windows. The most 


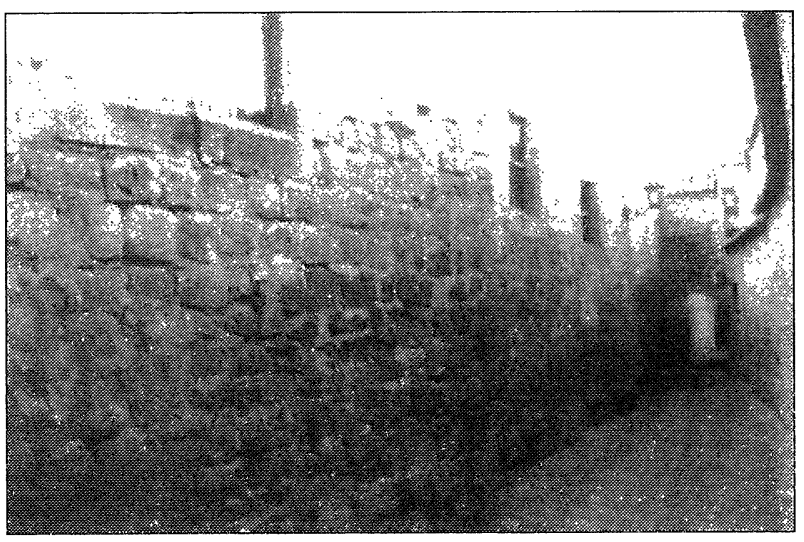

a) Humedad ascendente y agentes biológicos.

a) Rising damp and biological agents.

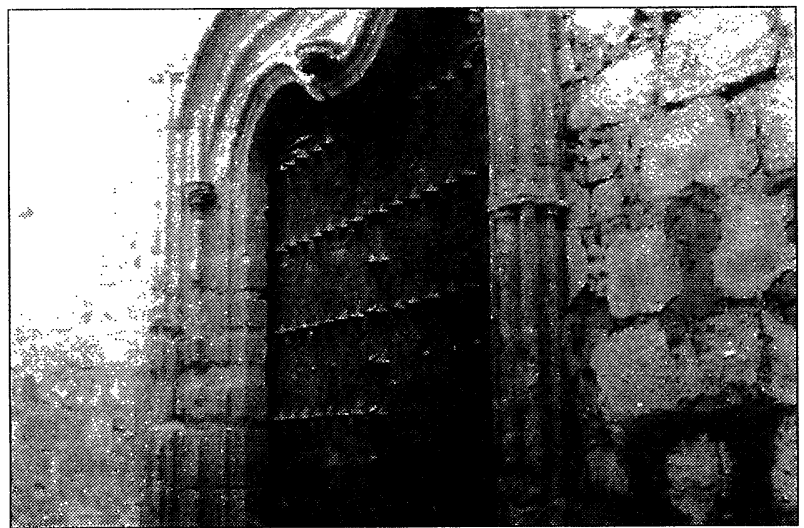

c)Alveolizaciones y excoriaciones.

c) Honeycomb weathering and excoriations.

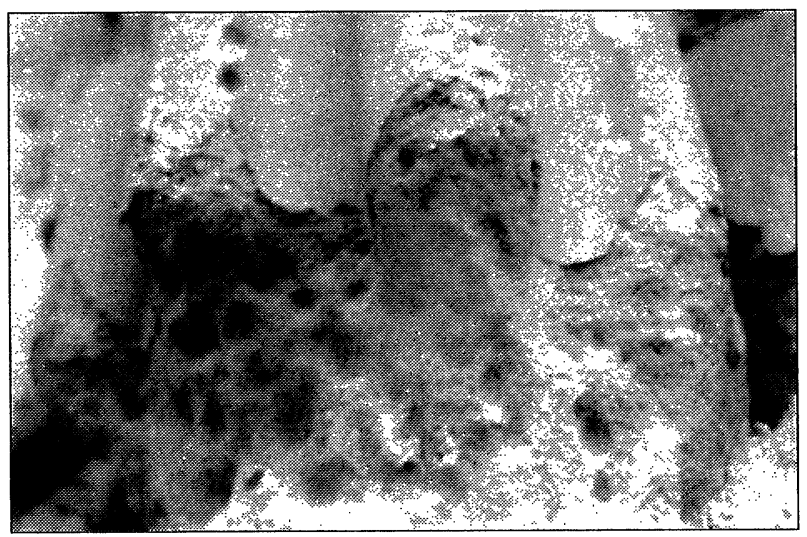

e) Fuerte costra superficial.

e) Strong superficial crust.

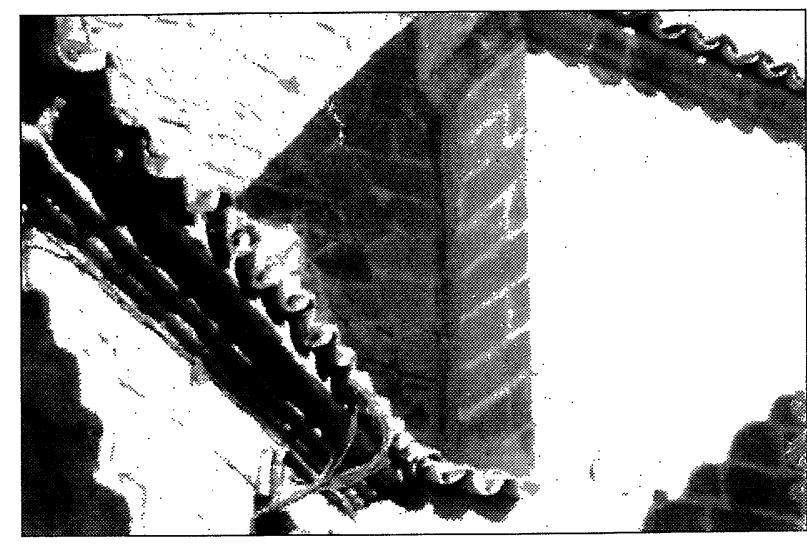

b) Fisuras verticales.

b) Vertical fissures.

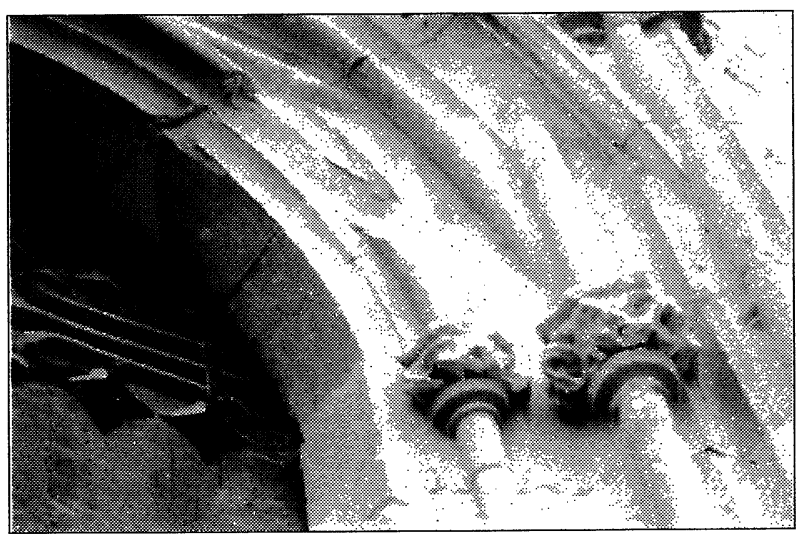

d) Fracturaciones y fragmentaciones.

d) Cracking and spalling.

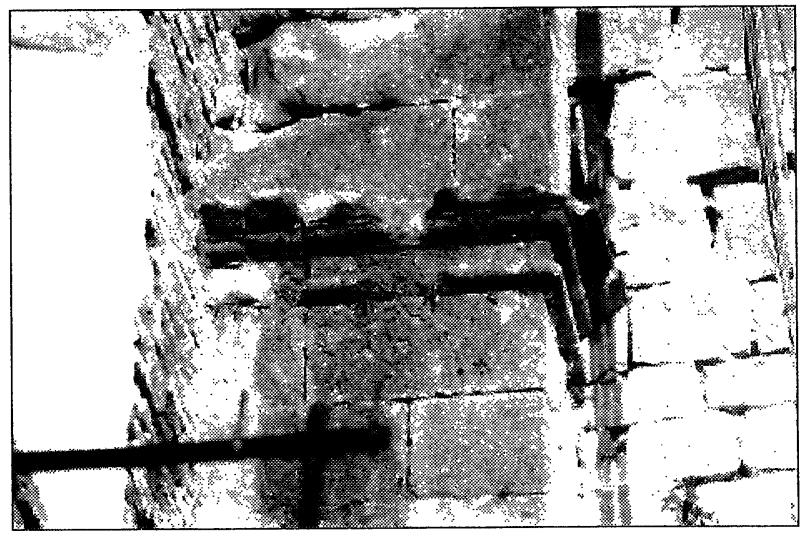

f) Fragmentaciones en las cornisas.

f) Spalling on cornices.

Figura 3.-Fachada Meridional. Catedral de Baeza.

Figure 3.- South Façade. Cathedral of Baeza. 


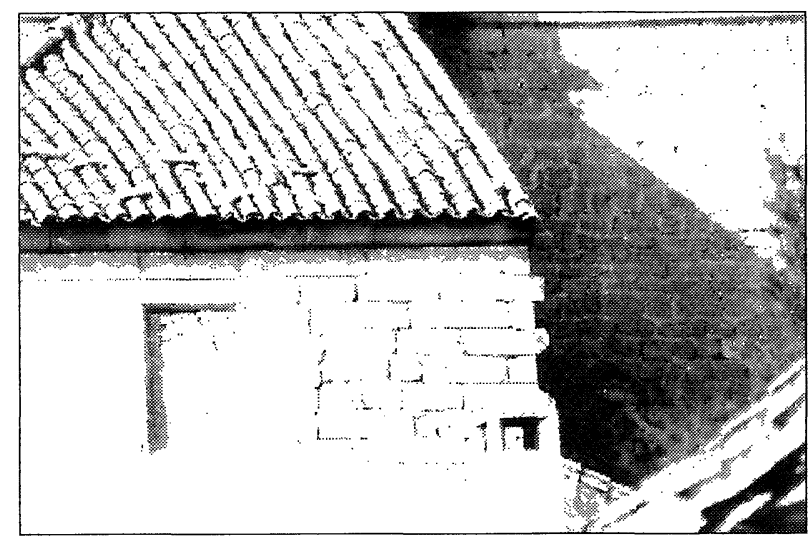

a) Pérdidas de mortero en juntas.

a) Losses of mortar on joints.

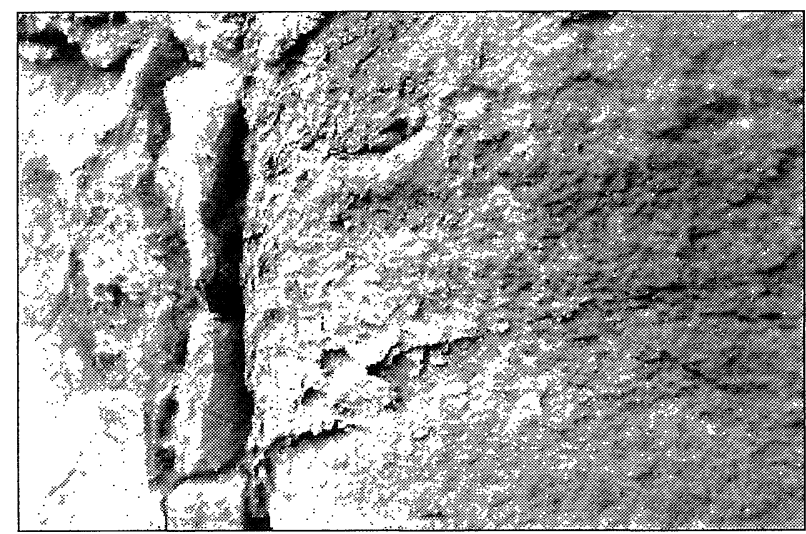

c) Arenizaciones y exfoliaciones s/estratos.

c) Grain disgregation and peelings v/layers.

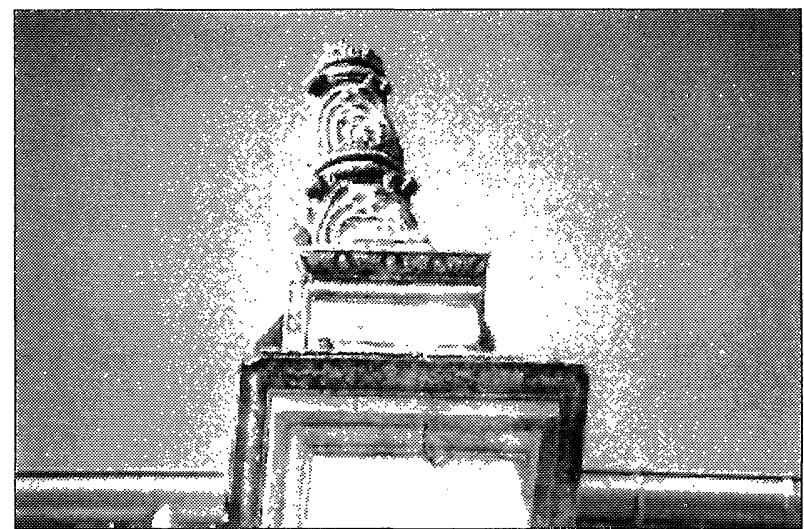

e) Pequeñas fragmentaciones en flameros.

e) Ligth spalling on torch-holders.

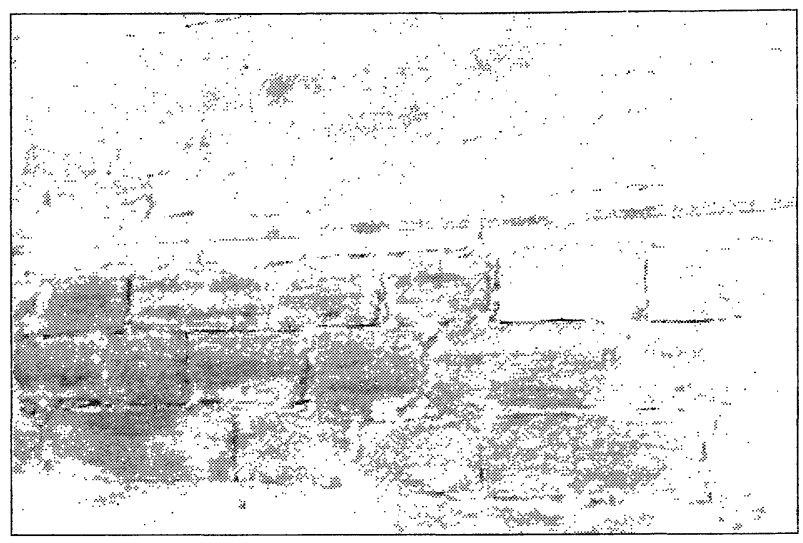

b) Fuerte estratificación en algunos sillares.

b) Notorious stratification on some ashlars.

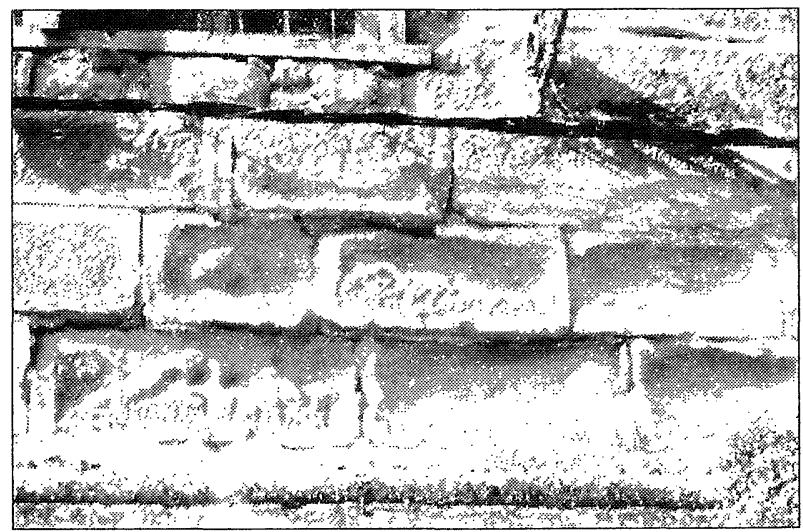

d) Cavernas en sillares, morteros compactos.

d) Caverns on ashlars, compact mortars.

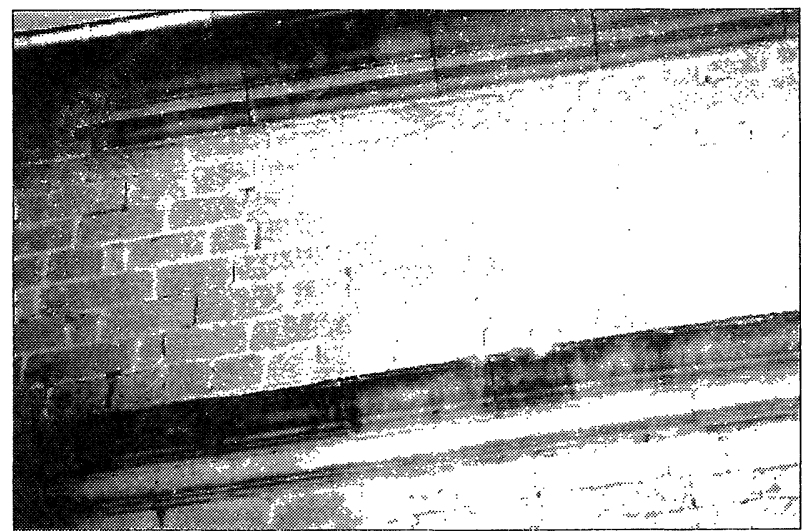

f) Fisuras de origen mecánico.

f) Fissures of mechanical origin.

Figura 4.-Fachada Oriental. Catedral de Baeza.

Figure 4.- East Façade. Cathedral of Baeza. 
elemento más deteriorado es precisamente el de mayor riqueza artística, la Puerta del Perdón, con sus baquetones y columnillas en un grado avanzado de deterioro (Figura 3b). La portada, que es la entrada al Claustro, es un elemento adosado que muestra importantes fisuras y fragmentaciones. Sus sillares centrales sufren importantes desplazamientos y necesitan reparaciones de sus juntas. También sus zonas bajas muestran importantes fisuras $y$ degradaciones de la piedra que pueden producir daños estructurales. Presenta arenizaciones, alveolizaciones, excoriaciones, disyunciones... (Figura 3c),

fracturaciones, fragmentaciones... (Figura 3d). Puede apreciarse aquí la fuerte pátina, realmente costra, dada su profundidad, que no será ajena a los antiguos encalamientos dados en épocas de epidemia de peste en toda la ciudad (Figura 3e). Otras fracturaciones se dan en las cornisas (Figura 3f).

\subsection{Fachada Oriental}

Sobresale un volumen, que corresponde a la Capilla del Sagrario (Figura 4a). El entorno ambiental lo define una calle estrecha, con casas en frente de poca altura, y ausencia casi total de tráfico; humedad ascendente hasta más de dos metros de altura, donde aparecen eflorescencias; abundante desarrollo de líquenes, mayor en las superficies orientadas al norte y en las molduras. Se observan pérdidas de mortero en algunas juntas entre sillares.

Grietas y fisuras se aprecian en las zonas bajas de fábricas de la esquina sur-este. Por su trazado parecen ser debidas a problemas de asientos del terreno. Como en el otro lado, la esquina de la cabecera de la Catedral muestra una grieta vertical, más marcada en la zona superior, y acompañada con algunas fracturas menores. En el ángulo del muro de la Capilla del Sagrario, estos problemas mecánicos han derivado en importantes fisuras inclinadas. En el interior se pueden apreciar importantes signos de humedades causados por problemas de la cubierta . La Capilla del Sagrario muestra el peor aspecto, con manchas oscuras a lo largo de toda la falsa cúpula de yeso, que también tiene problemas de unión con la piedra o las fábricas resistentes.

En los zócalos de los volúmenes adosados hay hileras de sillares con una marcada estratificación (Figura 4b). Los lechos marrones tienden a arenizarse mientras que los grises, de aspecto pizarroso, tienden a presentar exfoliaciones (Figura 4c). En algunos sillares, en que las aristas han sido endurecidas por los morteros de cal, las arenizaciones se presentan en forma de cavernas (Figura 4d). Esta es una señal típica del mal uso de morteros muy compactos que hacen que las migraciones de humedad encuentren un paso deteriorated element is precisely the most valuable one from an artistic point of view: Forgiveness Door, whose drumsticks and columns are in advanced weathering state (Figure 3b). The portal, which is an entrance to the Cloister, is an added element that shows fissures and spalling. The portal central ashlars show important displacements and they need their joints repaired. The lower zones of the portal also present fissures and degradation, which can generate structural damage. Some existing deteriorations are: grain disgregations, alveolar erosions, excoriations, disjunctions... (Figure 3c), fractures, spalling... (Figure 3d). The tough patina, which can be considered crust given its deepness, may be related to old limings applied to the whole town in epidemic times (Figure 3e). Other fractures appear in the cornices (Figure 3f).

\subsection{Eastern Façade}

The most important volume corresponds to Sagrario Chapel (Figure 4a). The environmental surrounding is defined by a narrow street, with low houses and almost no traffic. Rising dampness is perceived even over two metres height, with efflorescences, as well as developed amounts of lichens, especially on the north oriented surfaces and in the moulders. Loss of mortar material in some ashlars joints can be observed.

Both crevices and fissures are appreciated in the lower zones of the south-eastern corner masonries. Looking at their shapes, they seem to be caused by ground settlement problems. As in its opposite side, the Cathedral head corner shows a vertical crevice, more pronounced in the upper zone, and accompanied of some minor cracking. These mechanical problems have derived into the formation of leaning fissures in the angle of Sagrario Chapel wall. Inside, some serious dampness signs can be found, caused by roof problems. Sagrario Chapel shows the worse aspect of the entire building, with flowing dark tarnishes all over the false plaster cupola, which also presents problems to join the stones or the structural masonries.

In the socles of the leaning volumes, there are ridgepoles with noticeable stratification (Figure $4 b$ ). The brown layers tend to disgregate while the grey ones, of slate aspect, tend to presen t peelings (Figure 4c). Cavern shaped disgregations are present in certain ashlars whose edges have been hardened with lime mortars (Figure 4d). This is a typical sign of misuse of very compact mortar, which makes dampness migrations find their easiest way through the stone 
preferencial en la piedra y no en las juntas de sillares. De esta forma se desplaza la degradación de las juntas de mortero y bordes al centro de los sillares, a veces con peores consecuencias. Se observan disgregaciones en algunas cornisas y desagregaciones en los pies de los flameros que coronan los contrafuertes (Figura 4e). Como en el resto del edificio, las aristas y vértices de las cornisas presentan numerosas fragmentaciones, que también afectan a los labrados de los flameros (Figura 4e). También se encuentran fisuraciones, más bien episódicas, de origen mecánico (Figura 4f).

\subsection{Claustro}

El Claustro presenta una fábrica muy heterogénea y está en mal estado de conservación, principalmente el muro sur. Esta parte de la edificación muestra fisuras que son originadas por factores mecánicos y descomposiciones de los muros. Algunos de los accesos a las capillas han sido cegados con fábrica de ladrillo y, actualmente, se ha iniciado su restauración pero los trabajos se desarrollan muy lentamente.

La estructura de la cubierta original del Claustro ha desaparecido, siendo sustituida por una moderna, de. madera. Destacan algunas alteraciones de humedad en estas zonas. Signos puntuales de humedad pueden ser apreciados en las zonas bajas de la superficie; el lado exterior del muro sur de la nave lateral de la Catedral muestra claramente degradaciones de la piedra y reparaciones realizadas con otros materiales, justo en su encuentro con el faldón del Claustro (Figura 5a). El interior del muro sur de la Catedral muestra importantes humedades situadas en la misma altura.

Los pilares y paramentos del Claustro orientados al sur son los que presentan mayor grado de alteración, tanto exteriormente como interiormente, con abundantes eflorescencias de sales, sobre todo en las juntas entre sillares (Figura 5b), disgregaciones y arenizaciones. Exteriormente se observan algunas cavernas e interiormente, además de las arenizaciones (Figura 5c) importantes disyunciones, a veces exfoliaciones (Figura 5d).

Los agentes biológicos se presentan de forma generalizada en los paramentos exteriores, en la parte inferior de los pilares y en los paños laterales orientados al este (Figura 5e).

La zona inferior del muro lateral de la Catedral, interior del Claustro, con orientación sur, presenta serios problemas de humedad ascendente, asociada con sales, que conducen a importantes arenizaciones $\mathrm{y}$ disyunciones de placas (figura $5 \mathrm{f}$ ). instead of through the ashlars joints. In this way, degradation goes from the mortar joints and the borders to the ashlars centre, sometimes bringing along worse consequences. Some of the observed problems are disintegrations in some cornices, and disgregations in the flamboyant feet that crown the abutments (Figure 4e). As in the rest of the building, cornices edges and vertices present numerous spallings, which also affect other stoneworks. Fissures of mechanical origin are also found, but they occur occasionally (Figure 4f).

\subsection{Cloister}

The Cloister presents a very heterogeneous masonry and it is in bad state of conservation, especially the southern wall, which presents fissures originated by mechanical factors and by wall decomposition. Some of the chapel accesses have been closed up with brick walls, and, although certain restoration labours have been recently initiated, they are being developed really slowly.

The structure of the Cloister original roof has disappeared, and it has been substituted for a modern wooden one. These zones show some deteriorations caused by damp. Occasional moisture marks can be distinguished in the low zones of the surface. The external side of the southern wall of the lateral nave clearly shows some alterations and reparations, realized with other materials, just in the meeting point between that wall and the Cloister (Figure 5a). The inner side of the Cathedral southern wall shows important moisture at the same height.

\section{The highest degree of external and internal} deterioration appears in the Cloister pillars and in the south oriented paraments. These elements present numerous salt efflorescences, especially in the joints between the ashlars (Figure 5b), disintegrations and grain disgregations. Outwardly some caverns can be observed, as well as important grain disgregations (Figure 5c), disjunctions and, sometimes, exfoliations (Figure 5d).

In a generalized way, biological agents appear in the external paraments, in the pillars lower zones and in the east oriented lateral sides (Figure 5e).

The lower zones of the Cathedral lateral wall (the Cloister inside), which is south oriented, presents serious problems of rising dampness, together with salts; this association leads to important grain disgregations and contour scaling (Figure 5f). 


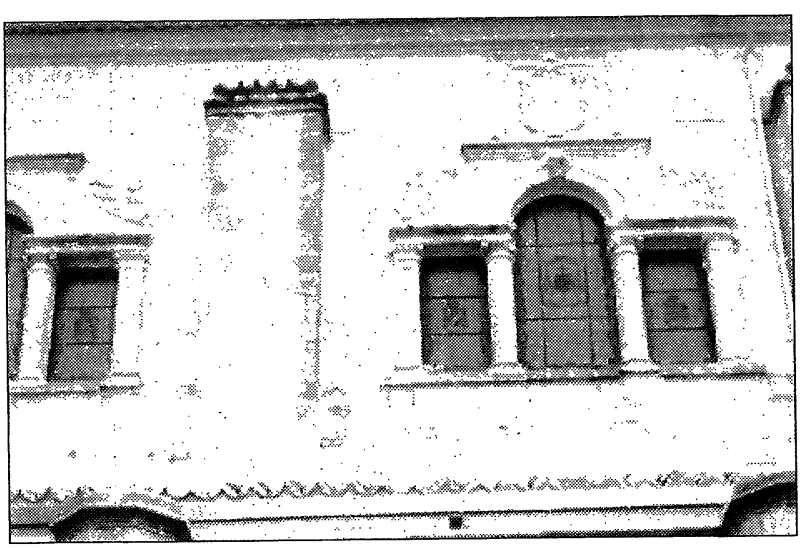

a) Humedad y reparaciones con mortero.

a) Damp and repairs with mortars.

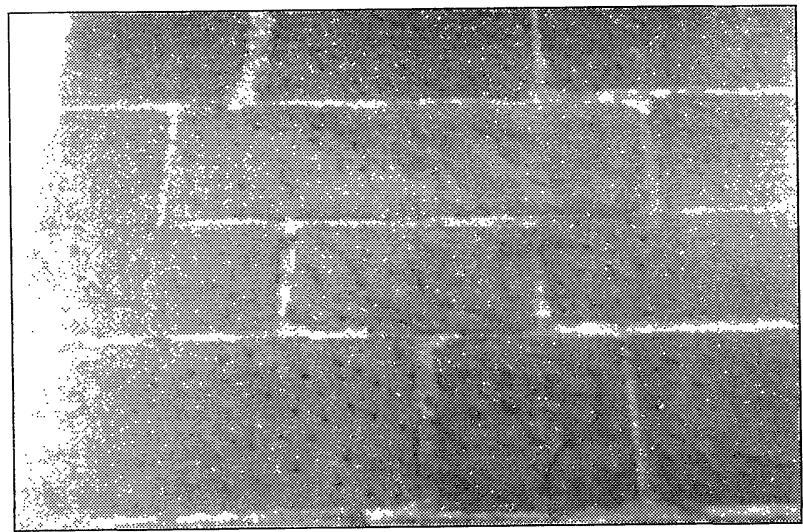

c) Arenizaciones en el interior.

c) Grain disgregations in the inside.

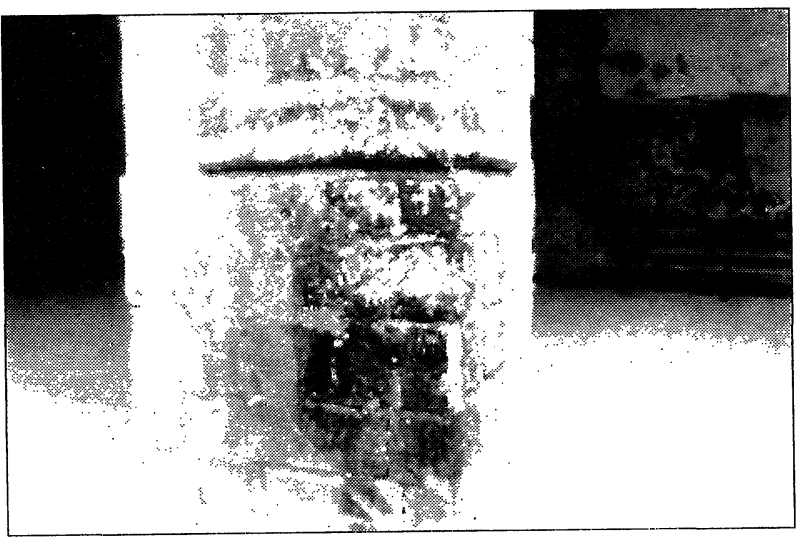

e)Agentes biológicos.

e) Biological agents.

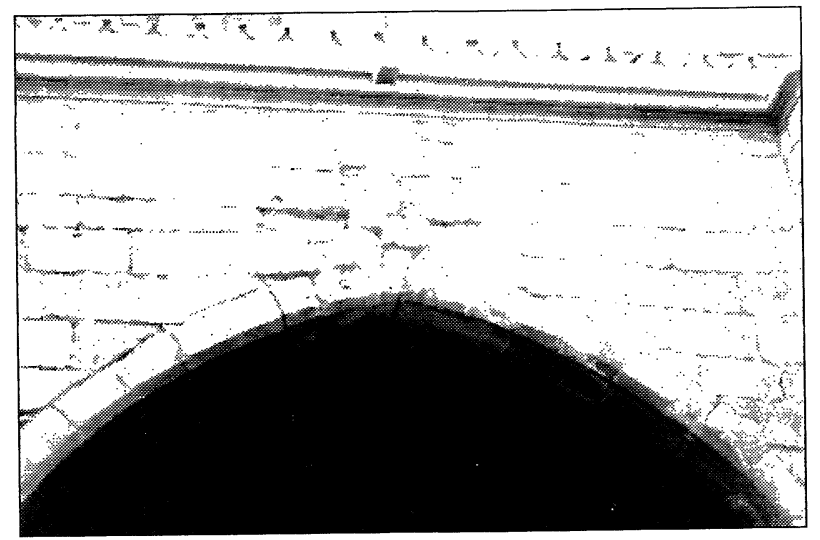

b) Eflorescencias, arenizaciones, cavernas.

b) Efflorescences, grain disgregations, caverns.

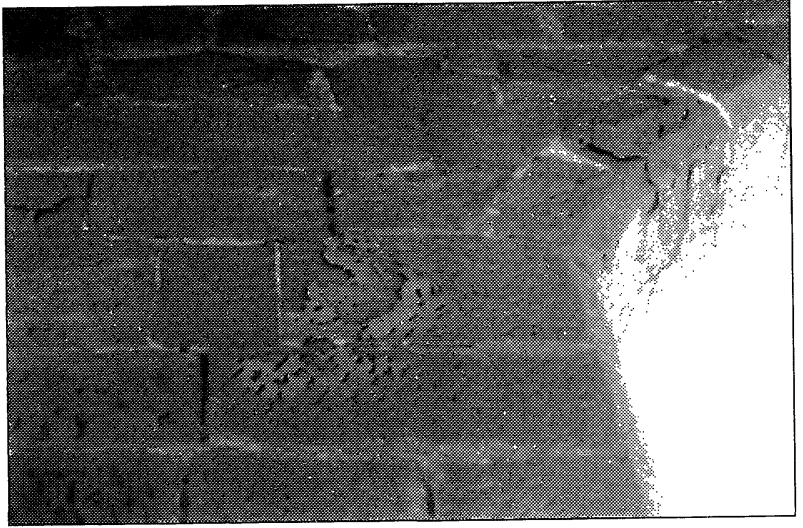

d) Disyunciones de placas.

d) Contour scaling

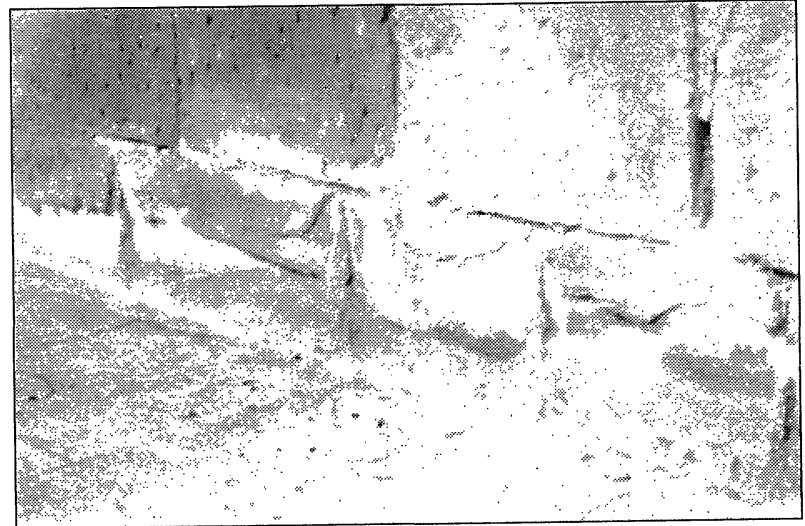

f) Eflorescencias, arenizaciones, disyunciones.

f) Efflorescences, grain disgregation, disjunctions.

Figura 5.-Claustro. Catedral de Baeza.

Figure 5.- Cloister. Cathedral of Baeza. 


\section{AGRADECIMIENTOS}

Al Instituto Andaluz del Patrimonio Histórico por su apoyo económico. A Jesús Espinosa y Esther Ontiveros por los difractogramas de Rayos X. A Eduardo Sebastián por los datos de propiedades mecánicas y por su estímulo. A Francisco Gómez por los datos de las intervenciones realizadas.

\section{ACKNOWLEDGEMENTS}

To the Instituto Andaluz del Patrimonio Artistico, for its economical support. To Jesús Espinosa and Esther Ontiveros for the X-ray power diffractograms. To Eduardo Sebastián for the information about mechanic properties and for his support. To Francisco Gómez for the information about the realized interventions.

\section{BIBLIOGRAFÍA}

(1) ALCALDE, M.: Sintomatología de alteraciones de las Catedrales. Universidad de Sevilla. 1990.

(2) Atlas Climático de España. INM. Madrid, 1983

(3) AYALA, P.: Antología Histórico - Artística de la ciudad de Baeza. Jaén, 1982.

(4) MEJÍAS, A. y SALAZAR, V.: Desde Baeza, 26 (1989), 1-7.

(5) MARTÍN, A: Ensayos y experiencias de alteración en la conservación de obras de piedra de interés histórico-artístico. Ed. Ceura. Madrid, 1990.

(6) OYA, V.: Baeza, del Renacimiento a hoy. Obra cultural de la Caja de Ahorros de Granada, 1979

(7) SEBASTIÁN, E., MARTÍN, J. y ZEZZA, U.: The "piedra dorada" calcarenite in the cultural built heritage of Baeza. Atti. Tic. Sc. Terra, 38 (1995), 205-213.

(8) VILLEGAS, R.: Tesis Doctoral. Ed. Universidad de Sevilla, 1990. 